\title{
Accounting Students' Perception Towards Virtual Money as Mobile-Payment During Covid-19 Pandemics: Evidence from Indonesia
}

\author{
$1^{\text {st }} \mathrm{R}$ Destiana Department of \\ Accounting Universitas Swadaya \\ Gunung Jati J1 Pemuda 32 Cirebon, \\ Indonesia \\ *destirin@gmail.com
}

\author{
$2^{\text {nd }} \mathrm{R}$ Wiradinata Department of \\ Accounting Universitas Swadaya \\ Gunung Jati Jl Pemuda 32 Cirebon, \\ Indonesia
}

\begin{abstract}
Virtual money as payment method plays crucial roles during the covid-19 pandemics. A plenty of research revealed the use of virtual money as the dynamic development of payment methods last ten years. Yet, little has been known from the accounting students' perception about the virtual money during the covid-19 pandemics. Thus, this research was attempted at portraying accounting students' perception toward the virtual money use during the Covidpandemics. Online survey and interview were conducted to collect the data. The findings show that despite their benefits which give ease and practicality of usage, using virtual money is perceived negatively contribute to criminal acts. Benefits from discount and voucher facilities also emerge during data analysis. In addition, promoting disrupted financial literacy is also resented and discussed.
\end{abstract}

Keywords-Accounting, Student, Virtual Money, Covid-19, Indonesia

\section{INTRODUCTION}

varieties of payment forms are freely developed shifting from time-to-time (1). The dynamic development of the money form into mobile-wallet (2) has provided many advancements. The benefits of the mobile-wallet include providing ease and practicality of the use. The development of digitalization of money as official payment method has driven to many virtual money such as bits, OVO, etc. This raising financial technological concept of generalization virtual means of payment is now getting recognized and discussed in last 5 years (3-7) which provides convenient cashless for any kinds of transaction. In addition, the use of virtual money has now negatively contributed to criminal activities due to cash delivery and usage.

Previous studies show for being addicted with the virtual money, e.g. for young consumers (2)(8). This fast changing of youth modes of transaction modes has attracted for business innovation which force to provide best services. This fast development of payment innovation is required to fulfill the social and commerce expectation. However, albeit a number of relating studies about virtual money, research in revealing accounting students' perception about virtual money is still rare. Thus, this research aimed at revealing how the accounting students perceive virtual money during their covid-19 pandemic.

\section{THE STUDY}

This current study was conducted in an accounting department of a private university where the researcher taught. This research situated in a small city in Indonesia which virtual money is widely used throughout mobilepayment in commerce shops. Designing a case study, the current research involved 120 participants. Of Participants 120 , sixty accounting students, aged 20-23 year old, were voluntarily recruited to participate in this study. The data were collected through online survey using Google-forms and distanced-interview using mobile phones.

\section{FINDINGS AND DISCUSSION}

A. Student virtual money preferences during covid-19

The results show that most students are familiar with OVO as the most frequent use of virtual money. This is possible as OVO various features in serving their youth consumers, e.g. buying daily needs, paying online services for their mobility and information, including their academic activities and services at the moments. The details of the accounting students' preferences in using virtual money are presented in the following figure 1 . 


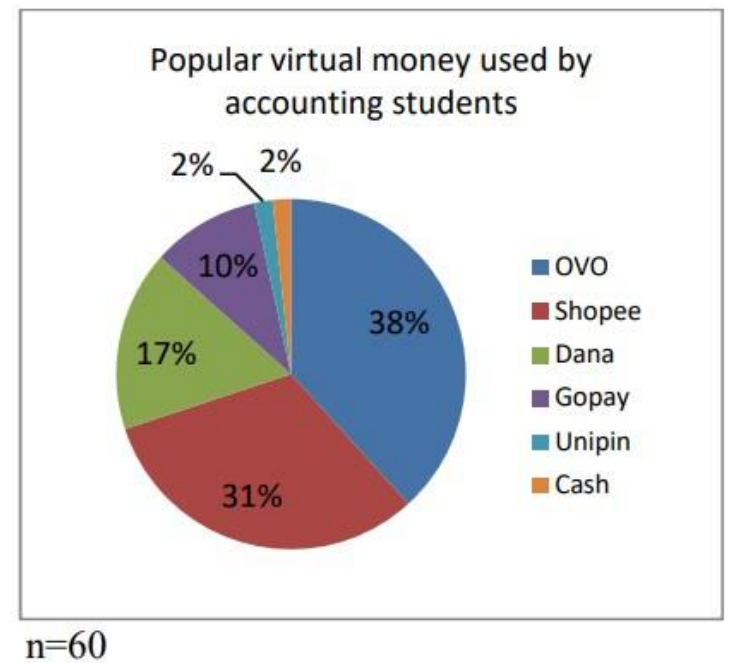

Fig. 1. Accounting student preferences in using virtual money

B. Accounting students' perception about virtual money This research deals with the accounting students' perception of using virtual money as mobile payment methods during Covid-19 pandemics. When OVO and Shopee virtual money suggest as the most widely used among the accounting students, the following interview except reveals their perception toward values within their practices in utilizing virtual money, e.g. advantages and issues. Seven issues emerge during the data analysis.

My experience has taught me virtual money as an alternative payment method which is effective and efficient (\#1). First of all, using virtual money (emoney) successfully reduces syndicate of money duplication(\#2). Moreover, criminal due cash delivery is also possible prevented. As university students, we know customized to use e-money due to its easy and flexibility (\#3), for an example, no need for saving wallet. Gopay, OVO, etc. are now available for goods and service payment everywhere. No need to worry money lost(\#4). Efficiency occurs when the electronically transaction takes place. It consume timeless for the payment and refunds(\#5), saving more time for other activities due queues, when I am on the highway for an example. In the other advantages, I think virtual money is eco-friendly to support green ecology(\#6). and you know what? The most interesting advantage of virtual money for us as students is discount up to $100 \%$ off through its cash-back services. This is very useful for us that we can buy another goods using voucher and points(\#7) (KA, 21 year).

The first issue is due Effective and efficient use. Virtual money was perceived as an effective and efficient payment method. This mobile payment method is an alternative during the Covid-19 pandemics. As told by KA (21), using virtual money has taught her to use an opt of effective and efficient payment method. She explained, "My experience has taught me virtual money as an alternative payment method which is effective and efficient (1). This kind of students feel empowered by using virtual money as an alternative payment method as she knows how to use it effectively.
Second is due Criminal avoidance. Using virtual money is also regarded as a good strategy in preventing criminals, e.g. cash robbery and syndicate of artificial money. As she said, "Using virtual money (e-money) successfully reduces syndicate of money duplication(2)". She discovered the use of virtual money positively makes and involves against the criminal due to money-caused criminals.

Practicality of use: easy and flexibility. Addicted, accounting students perceive virtual money for its ease and flexibility use. The accounting students are accustomed using virtual money for their routines, e.g. buying goods and asking for services related to their academic schemes. Since cashless go with them, they need no cash in their wallets any longer. The student reveals, As university students, we know customized to use e-money due to its ease (3) and flexibility, for an example, no need for saving wallet. Gopay, OVO, etc. are now available for goods and service payment everywhere.

Secured money: no worry. The findings reveal that virtual money provides sense of secure for travelling or adventures without any worries to lost the money. Since virtual money is always stored in smart mobile phone application, the money is highly protected in system, e.g. needs authentication for each access and encrypted by passwords and codes. Therefore, the owners feel safe to have the money. As the student said, "No need to worry money lost(4)". Efficiency occurs when the electronically transaction takes place Refunds, discount and point rewards. Accounting students are economists. They learn to earn more values using less money. This principle is valid for them because using virtual money earns more refunds and discounts while point rewards are collected, too. These facilities attract accounting students and find their contexts - accounting study - to implement their accounting knowledge in practice. A student found, It consume timeless for the payment and refunds(5), saving more time for other activities due queues, when I am on the highway for an example.

The most interesting advantage of virtual money for us as students is discount up to $100 \%$ off through its cashback services. This is very useful for us that we can buy another goods using voucher and points(7)

Eco-friendly: Promoting green ecology. Using virtual money takes part in saving the earth campaign. Different from cash money, virtual money leave nil pollution. Cash money, for an example, supplies a number of garbage. In addition, coins will remain undestroyed. As a result, there is no recycle natural process. This finding gives a new insight of a point of view from accounting students. The student argued, "I think virtual money is ecofriendly to support green ecology(6)". Her argument gives a new insight and directions of further campaign not use cash too often in order to fight against pollution.

So, using virtual money is, in fact, contributing to keep the earth safe and secured for human being. It is important to pay attention to customers' behaviors to support their abilities in using virtual money throughout their mobile devices (8). Supporting infrastructures are needed to give senses of comfort and secured to the customers of virtual money $(9,10)$. To this, virtual money users should be well- 
educated to wisely use their mobile devices due to several negative reasons, e.g. addiction, mental illness, etc. (9)

\section{CONCLUSION AND RECOMMENDATION FOR FURTHER RESEARCH}

It concludes virtual money is perceived as valuable, secured, and practical. The findings also suggests that in terms of varieties of the virtual money, students' financial literacy requires to develop to provide more access and praxis in the erupted financial technology of virtual money which provides maximum advantages. Thus, further investigation is required to provide new insights from this new perspective of student financial technology literacy.

\section{REFERENCES}

[1] Hofmann C. The Changing Concept of Money: A Threat to the Monetary System or an Opportunity for the Financial Sector? [Internet]. Vol. 21, European Business Organization Law Review. Springer International Publishing; 2020. 37-68 p. Available from: https://doi.org/10.1007/s40804020-00182-Z

[2] Shaw B, Kesharwani A. Moderating Effect of Smartphone Addiction on Mobile Wallet Payment Adoption. J Internet Commer [Internet]. Routledge; 2019;18(3):291-309. Available from: https://doi.org/10.1080/15332861.2019.1620045

[3] CPMI. Distributed ledger technology in payment, clearing and settlement: an analytical Framework Technical report, Bank for International Settlements. Committee on Payments and Market Infrastructures. 2017.

[4] CPMI. Digital currencies. Technical report 137, Bank for International Settlements [Internet]. Committee on payments and market infrastructures. 2015 [cited 2018 Jan 1]. Available from: http://www.bis.org/cpmi/publ/d137.pdf

[5] IOSCO. Research Report on Financial Technologies (Fintech) [Internet]. Technical report, International Organization of Securities Commissions. 2017 [cited 2018 Jan 1]. Available from:

https://www.iosco.org/library/pubdocs/pdf/IOSCOPD554.pdf

[6] Pearlman L. Distributed Ledger Technologies and Financial Inclusion [Internet]. Technical report, International Telecommunications Union. 2017 [cited 2018 Jan 1]. Available from: http://www.itu.int/en/ITUT/focusgroups/dfs/Documents/201703/ITU_FGDFS_Reporton-DLT-and-Financial-Inclusion.pdf

[7] Reiss DG. Is money going digital? An alternative perspective on the current hype. Financ Innov.Financial Innovation; 2018; 4(1):0-5.

[8] Liébana-Cabanillas F, Muñoz-Leiva F, Sánchez-Fernández J. Behavioral Model of Younger Users in M-Payment Systems. J Organ Comput Electron Commer. 2015;25(2):169-90.

[9] Bailey AA, Pentina I, Mishra AS, Ben Mimoun MS. Exploring factors influencing US millennial consumers' use of tap-and-go payment technology. Int Rev Retail Distrib Consum Res [Internet]. Routledge; 2019;00(00):1-21. Available from: https://doi.org/10.1080/09593969.2019.1667854

[10] Chiu IHY. A new era in fintech payment innovations? A perspective from the institutions and regulation of payment systems [Internet]. Vol. 9, Law, Innovation and Technology. Taylor \& Francis; 2017. 190-234 p. Available from: https://doi.org/10.1080/17579961.2017.1377912 